\title{
Examining the Role of Brazilian Navy before Alcohol Intake in the Workplace
}

\author{
Elizabeth Espindola Halpern, Ligia Costa Leite \\ Institute of Psychiatry, Federal University of Rio de Janeiro, Rio de Janeiro, Brazil \\ Email: espindolahalpern@yahoo.com.br, ligia.cleite@gmail.com
}

Received December 21 $1^{\text {st }}$ 2013; revised January $16^{\text {th }}, 2014$; accepted February $14^{\text {th }}, 2014$

\begin{abstract}
Copyright (c) 2014 Elizabeth Espindola Halpern, Ligia Costa Leite. This is an open access article distributed under the Creative Commons Attribution License, which permits unrestricted use, distribution, and reproduction in any medium, provided the original work is properly cited. In accordance of the Creative Commons Attribution License all Copyrights (C) 2014 are reserved for SCIRP and the owner of the intellectual property Elizabeth Espindola Halpern, Ligia Costa Leite. All Copyright (c) 2014 are guarded by law and by SCIRP as a guardian.
\end{abstract}

\begin{abstract}
This article presents some of the results of a qualitative research conducted at the Center for Chemical Dependency (CEDEQ) of Brazilian Navy, a specialized outpatient clinic for substance abuse, in order to investigate the role of this institution in the construction of the military patients' alcoholism. A participant observation was carried out in two treatment groups, during 24 sessions, in 2010. In addition, individual open-ended interviews with 13 patients were carried out after each group session. According to their narratives they tend to believe that the institution both stimulates and prohibits the consumption of alcohol on board, an ambivalent position that contributes to the production of alcohol addiction in these individuals. As a result, the incorporation of standards of conduct related to alcohol consumption throughout their military career was observed, creating drinking patterns, especially drinking with colleagues of their military units, which we named alcoholic habitus.
\end{abstract}

Keywords: Alcoholism; Occupational Health; Working Conditions

\section{Introduction}

Brazilian Navy created, in 1997, the Center for Chemical Dependency (CEDEQ), a specialized outpatient clinic for the treatment of chemical dependency, located in the Navy Central Hospital. This center is a pioneer initiative of Brazilian Navy, unprecedented in Brazilian Armed Forces, a milestone that reflected the official beginning of activities directed towards the treatment of drug addicts. Despite the advances of the actions in the area of prevention, treatment, and rehabilitation little is known about the impact played by naval workplace in the production of alcoholism of the patients. The inaugural studies on this issue have recently been made by the authors of this article, derived from their investigations in CEDEQ.

\section{Context}

The treatment program consists of group therapy that occurs throughout five steps: motivational group, phase I, II, III, and consolidation group. The permanence in each phase may vary depending on individual performance throughout the treatment. Above all, it is expected that the patient reaches abstinence and changes his patterns of behaviors and ways of thinking. The treatment involves compliance with specific objectives required in each stage, based on behavioral techniques and on the 12 steps and 12 traditions of alcoholics anonymous recommendations. Influenced by these guidelines, the program focuses on group treatment, believing that sobriety can be best achieved with the group support (Alcoholics Anonymous, 1996).

Although CEDEQ is available for all military personnel from the age of 18 , the vast majority belongs to the enlisted rank. In contrast, officers rarely seek help on CEDEQ, preferring private sessions. The enlisted military personnel are the numerical majority of the organization and are the base of the pyramid chain of Command. In general, they are responsible for equipment operation and maintenance of the facilities of their military units (Brasil, 1980).

\section{Methodology, Collecting Process, and Data Analysis}

A qualitative study was conducted through the ethnographic method, based on participant observations (Malinowsky, 1922/ 1984; Minayo, 2006; Minayo, Deslandes, \& Gomes, 2007) in two therapeutic groups, each consisting of, approximately, ten members, in 24 sessions, in 2010. Additionally, a multiple case study (comparative) and explanatory (Yin, 2005) was carried out through individual open-ended interviews (Fossey et al, 2002). For such, 13 patients were selected among the 25 patients who were part of two motivational groups, a phase that corresponds to the first stage of the treatment program. The interviews took place after the group sessions about their involvement with alcohol in the workplace. Data interpretation was possible by using the Peircean abduction (Peirce, 1935) of the peculiar categories that emerged in the discourse of the subjects (Boudon, 1998).

\section{Results, Analysis, and Discussion of Data}

A Templum-synthesis was built according to the diagram of Boudon (1998) to analyze and discuss the information: 


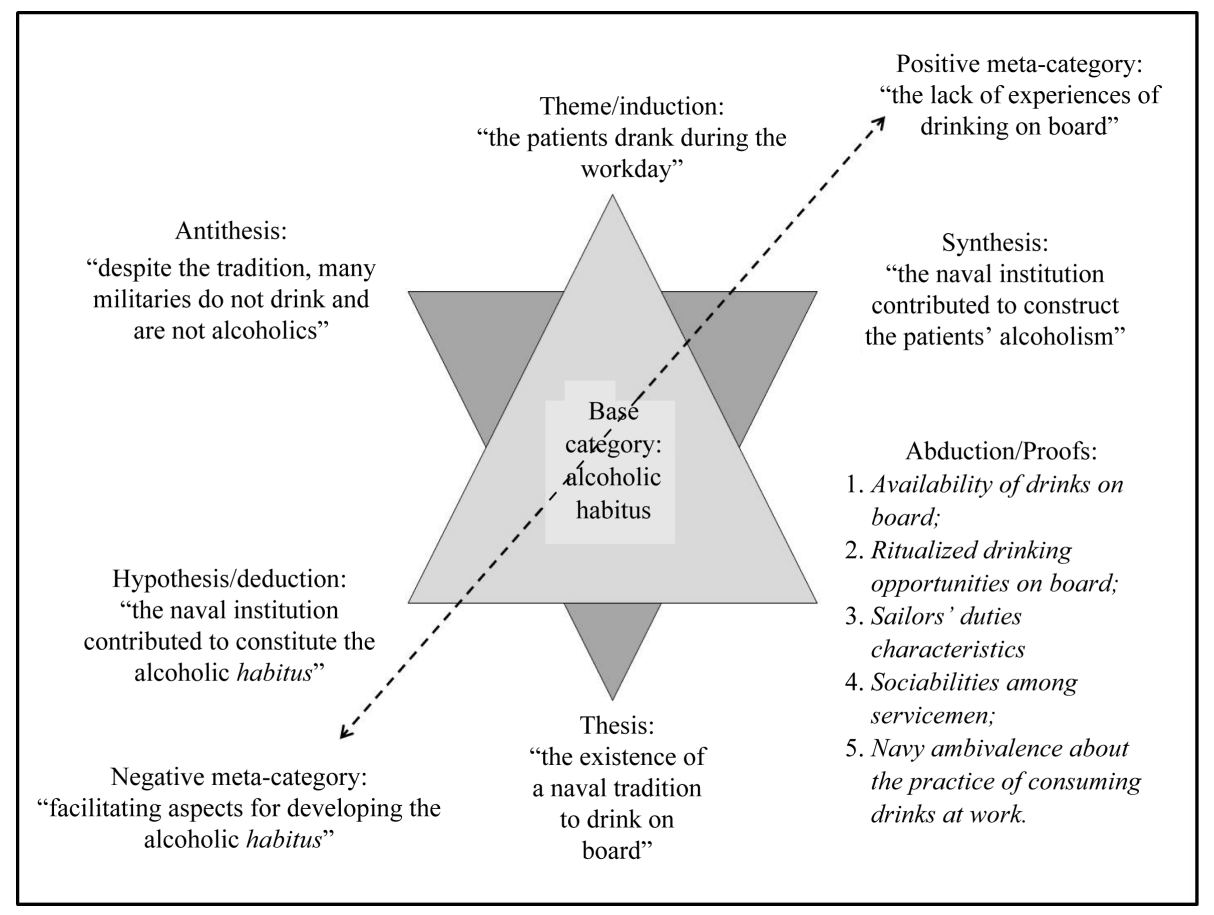

Below, each element of the Templum will be developed in order to further their meanings:

\section{Base Category: Alcoholic Habitus}

First of all, the base category identified the existence of "the social construction of alcoholic habitus". The alcoholic habitus (Halpern \& Leite, 2011a) incorporates the concept of habitus proposed by Bourdieu (2007), applying it to a pattern of behaviors, attitudes, and ways of thinking related to manners of ingesting alcohol, which is gradually assimilated. This research focused on emphasizing the socio-cultural dimension of alcoholism understood as a phenomenon, distinct from the prevailing perspective of the biomedicine which usually considers the addicted as one who has a mental and behavioral disorder due to the use of alcohol (WHO, ICD-10, 1993).

More than being a pathological trait, alcohol consumption is seen as an intrinsic practice necessary to consolidate a social bond, a lifestyle, a trace of culture. When we go to the drills, we form one team according to the preference of the group: if people drink, everyone must drink, no one can break this deal. Additionally, it has a social or symbolic function that change according to the context of its use (Douglas, 1987; Fainzang, 2007). Consequently, this study investigated the extent to which military life in Brazilian Navy contributed to the social construction of alcoholic habitus in these subjects. The report of one patient demonstrates this point: Ah! The vibes contributed to my alcoholism, for sure! All warehouses that I've worked in Navy always had the blessed "cachaça"1 (a kind of sugar cane brandy)!

\section{Positive and Negative Meta-Categories}

The base category ("the social construction of alcoholic habitus") was mediated by two meta-categories: one positive and

${ }^{1} \mathrm{~A}$ kind of sugar cane brandy. one negative that correspond to the possibilities of developing the alcoholic habitus. In order to achieve a dynamic analysis of this core category, the meta-categories indicated that can it can oscillate along two diametrically opposite poles: positive and negative. The positive meta-category indicated "the lack of experiences of drinking on board" for several reasons (fear of losing control, for religious beliefs, and for medical advice). The negative meta-category corresponded to "facilitating aspects for developing the alcoholic habitus", such as the availability of alcoholic beverages at work, the peculiarities of naval work, the collective experiences of consumption, and on account of the ambiguity of the institution before the issue of consumption of drinks during working hours (Halpern \& Leite, 2011b). Consequently, a network of meanings crossed with the other proofs that were concomitantly being woven in this dynamic process, highlighting elements that were implied and uncovering new facts.

\section{Theme/Induction: "The Patients Drank during the Workday"}

The theme of analysis that was induced revealed that "the patients drank during the workday". The theme was structured based on the reports of the patients who used to say that they drank during working hours. This information was widely shared by them during their group meetings. They explained that the consumption of alcohol is a common practice in the navy, not only among members of the enlisted rank, but it is also a custom in the daily routine of many officers: I worked on a ship that had brews in almost every occasion! All of this is an encouragement to drink. Many patients said that they began to consume alcoholic drinks when they joined the navy. Throughout their naval career, they confirmed that the amount ingested progressively increased, becoming a daily necessity. They informed that they used to drink not only during the commemorative events or to perform arduous tasks; the presence of alco- 
holic beverages is widespread on different occasions and settings of their quotidian. Last Thursday there was an event at the base. People got heavily wasted until the end of the day. It was sponsored by the headquarters itself, because of the Battalion's anniversary. In fact, beverages can be easily found in different military units, canteens, and dining areas, distributed with or without the acquiescence of the Command, mainly beer and "caipirinha",

\section{Hypothesis/Deduction: "The Naval Institution Contributed to Constitute the Alcoholic Habitus"}

Based on the theme it was possible to deduce a hypothesis. However, despite the similar experiences of drinking on the job, in general, patients are not fully aware of the possible correlation between the presence of drinks on board and the development of their alcohol addiction. Still, they use to share the situations in which they drank during the working hours: Those who work embarked know the cleaning system of the ship. This happens when we arrive at the port, you know? It is a heavy job, scrubbing and cleaning all day long! Then, the chiefs distribute "cachaça" to accomplish these tasks.

Many patients began to understand the influence of the environmental factors in the construction of their alcoholism along the treatment, especially from the discussions at the meetings. At the beginning of the treatment, they tend to deny their addiction. However, some of them usually take the full blame for their mistakes. In both cases, they have their self-confidence shaken. After a few weeks of treatment, developing closer ties with group members and therapists, the patients feel more comfortable to amusingly share their mischiefs and pranks, as well as episodes of collective drunkenness, revealing how the distribution of beverages occurs, even in the course of military drills. Alcohol appears in their discourse as a protagonist, as a bond that reinforces complicity and cohesion.

Even with the advancement of therapy, fighting for abstinence, alcohol continues to be a mixed experience of pleasure, pain and fear. Although many developed a critical view on the appropriateness of drinking on board, conceived by common sense as an inherent custom in all "Navies", they feel resigned before the force of the naval tradition of drinking. Consequently, patients sought strategies to overcome the temptation that emerges within the military organization, avoiding celebrations, ceremonies, cocktail parties, in other words, evading every opportunity where drinks are present. However, considering that the habit of libation remains entrenched in naval routine, they are required to engage in an incessant struggle. Unfortunately, the vast majority fails, unable to resist temptation and stay sober, fully assuming the blame for the failure. In fact, they do not deny the desire for drink, or the desire to enjoy the opportunities to drink on board. Additionally, it is believed that many of them do not wish that the distribution of beverages will be reduced or prohibited. After all, alcoholic beverages are the central components on the menu of the social life. Society itself corroborates the perception that drinking is desirable, until the moment when the libation brings clear damages to the individual.

\section{Abduction/Proofs}

Then, five proofs were abducted from the narratives to prove

${ }^{2} \mathrm{~A}$ cocktail made with "cachaça” or vodka, sugar and lime. the hypothesis. They were organized and will be presented separately to facilitate the analysis process, although, in reality, they are intertwined:

\section{(1) Availability of drinks on board}

In the Navy, on Fridays we have the famous "feijoada" 3 and "caipirinha”. It's a tradition! Everyone knows it. It will always be like this: tradition! Alcoholic beverages are within the reach of the military, sometimes with the agreement and/or the participation of the superiors: Each one takes his share of drinks in the maneuvers. In the intervals, everyone takes a sip. If you don't, you can't stand the heavy drills. The captain knows what's going on, but pretends that he is not aware.

\section{(2) Ritualized drinking opportunities on board}

Occasions seem to be created where alcohol comes into play. In fact, there are many pretexts to party, like birthdays, the arrival of new members, farewells, and promotions to higher positions:

Drinking on board is easy. On the ship there are many events, parties; then, you drink a lot! It is tradition in the Navy: every day, without authorization, but the staff knows: this is an ancient custom. The whole crew drinks, whisky, vodka, liquor, beer, as long as it makes one relax. It is traditional in the Navy! Last week there were four events. I can't tell what they celebrated, but there was food and drink at will.

In fact, there are many occasions in which alcohol is often called upon to be a protagonist which helps to consolidate the alcoholic habitus. There seems to be a pedagogy of drinking (Halpern \& Leite, 2010; 2013) that "teaches" military personnel to drink according to codes of sociability between mates. It cannot be resumed as a mere act of pouring liquid inside the body; above all, it is a learning process that is assimilated in daily work, until it becomes visceral: I usually go to the clubs with my coworkers. Total craziness! Entertainment, women, and drinks! We finally relax and have fun. There, we forget all the troubles.

\section{(3) Sailors' duties characteristics}

The proposed terminology named sailors' duties (Halpern, Ferreira, \& Silva Filho, 2008; Halpern, Leite, \& Silva Filho, 2010; Halpern \& Leite, 2013) refers to naval working conditions, organization, and processes that can lead to diseases and suffering of workers. In response, many of them seek support by drinking beverages wishing to minimize physical and mental strain. The peculiarities of the naval tasks constitute the third proof abducted of the narratives of the patients: Those who work on ships don't have time to go home. When we reach the port, I'm already determined to drink and have fun! We work a lot, but later the superiors sponsor a barbecue with beer at will!

\section{(4) Sociabilities among servicemen}

This is the fourth proof that complements the previous ones, since all of them belong to the same structure. Modes of social interaction of the servicemen usually occur in a universe in which they seek to express their likes, dislikes, joys, sorrows, and resentments. The existence of access codes seems to be necessary to join the peculiar sociabilities of naval life, thus, in general, individuals need to be acquainted with these codes (Halpern \& Leite, 2012). Actually, the sociabilities among servicemen need to be learned, mainly because they tend to occur in groups: We have fun when we have a great day out at a barbecue, then we play soccer, and drink some beers! Best fun

${ }^{3}$ It is a typical dish in Brazil, a stew of beans with pieces of sausage, pork and beef. 
ever!

In fact, the kind of leisure most cited by the patients is relaxing in the bars with co-workers, frequently located near their military units: When I get home, I'm usually nervous, impatient with the kids. My wife just complains. I'd rather go out with my buddies to the bar, they understand me and we laugh.

(5) Navy ambivalence about the practice of consuming drinks at work

This latest evidence concerns a fact that is widely cited by the patients, that is, a kind of discrepancy regarding the content of the regulations and the ambiguity of their implementation in daily life. The application of the rules varies depending on the circumstances and according to the judgment of each command: Sometimes they encourage drinking, especially to finish the tasks. Depending on the Command, they decide to arrest us. Nowadays, they refer the military to CEDEQ to avoid problems with the "law".

The institution seems to be complacent with the use of beverages in the workplace, interpreting as "normal" the frequency and amount of alcohol that is consumed in naval celebrations (Halpern, Ferreira, \& Silva Filho, 2008). Within the elastic category of "social drinkers", the chiefs and supervisors tend to tolerate many episodes of alcohol intoxication, leaving aside the regulation, particularly because they also adhere to these practices.

\section{Thesis: "The Existence of a Naval Tradition to Drink on Board"}

The observation of all these elements allowed the emergence of new arguments, namely, the thesis that revealed "the existence of a naval tradition to drink on board”. An inverted triangle could be drawn as an effect of progression of database analysis of the Templum. Therefore, through the evidence that was presented above, the thesis asserts the existence of a naval tradition of drinking alcohol at work that allows the constitution of the alcoholic habitus.

\section{Antithesis: "Despite the Tradition, Many Patients Do Not Drink and Are Not Alcoholics"}

The antithesis advocated that, in spite of the naval tradition of consuming drinks in the workplace, many members of Brazilian Navy do not drink alcohol or are alcoholics: Navy is divided into two groups: those who drink and those who are religious. The guy who doesn't drink is a fool or a spy. I stopped drinking and the pressure continues. The colleagues are teasing me, saying I'm a snitch.

Furthermore, it is not possible to predict whether a "social" consumption pattern will become a harmful one, considering that, along the years, one can become a heavy user or a dependent. The boundaries between the "normal" drinking and "pathological" one are tenuous, not only considering the individual differences, as well as environmental impacts. Therefore, it is not likely to affirm that the naval tradition of drinking on several occasions determined the constitution of alcoholism in these patients.

\section{Synthesis: "The Naval Institution Contributed to Construct the Patients’ Alcoholism”}

The synthesis of the Templum analysis confirmed the initial hypothesis ("the naval institution contributed to construct the patients' alcoholism”). However, this proposition cannot be extrapolated to the entire naval universe.

In this study, it was possible to verify its ambiguous position, sometimes encouraging the consumption of beverages in the working day, sometimes forbidding it, based on the regulations, punishing the drinkers who disregarded the prescriptions of each command: Booze are not permitted, but there are some military units that allow them. Some Captains authorize, while others, don't.

First, it is recognized that there are individual differences as to how to react to the conditions, processes, and organization of the naval labor. There are also different forms to adhere to sociabilities that require drinking beverages, preferably in groups. While many drink severely, some will not become addicted. However, the desire for a "glass" seems to be a common solution to diminish the stress and suffering on board.

The synthesis of the Templum analysis revealed that although the subjects investigated have oscillated between positive/negative meta-categories, there was a greater attraction in the direction of the negative meta-category. Therefore, the results of the observations and the interviews suggested that many patients developed the alcoholic habitus, particularly due to the availability of beverages and opportunities to drink, because of the peculiarities of the naval tasks that engenders strain, and because of the ambivalent position of the institution before the issue of drinking on board: Every Friday is happy hour on board. In every corner near the Battalion there is a bar! My colleagues invite me to drink every day. The TV displays beer all the time. It is difficult to stop drinking.

Finally, since the themes were analyzed by the alternative argument as proposed by Boudon (1998), the evidence abducted of the narratives corroborated the hypothesis that the Brazilian Navy facilitated the alcoholism of the subjects studied. Thus, the alcoholic habitus was the result of a social and institutional construction. Although there is a naval tradition that encourages the consumption of beverages (thesis), inside and outside the organization, there is a possibility that many individuals reject this custom (antithesis). Still, there seems to be an effect, at the same time coercive/permissive, about the practices of alcohol intake on naval workplace, which acts insidiously, making itself present at different moments, to celebrate and to console.

\section{Conclusion}

The ambiguous position of the naval organization regarding the use of alcohol in the workplace shakes the foundations which are necessary for the crew, as they provide guidance and protection. The transparent and consistent application of the regulations to all members of the naval contingent, guided by clear rules, helps to ensure the physical and mental integrity of the worker itself. Otherwise, he becomes more vulnerable to stress and suffering (Brant \& Minayo-Gomez, 2005), increasing his chances of using alcohol to achieve comfort.

Finally, the voices of the interviewees may help naval leaders understand that the availability of alcohol and drinking opportunities in military units played a central role in the construction of alcoholic habitus of these patients. It is believed that other military personnel of the corporation may be equally vulnerable to the harmful effects of consuming beverages on board, though they are not being treated at CEDEQ (yet). Consequently, pro- 
tective measures for workers could minimize human and material damages in Brazilian Navy.

\section{REFERENCES}

Alcoholics Anonymous. (1996). O grupo de AA: Onde tudo começa. São Paulo: JUNAAB.

Boudon, P. (1998). L'abduction et le camp sémiotique. In G. Brunel (Ed.), Le tiers communicationnel: Communication, légitimation, abduction (pp. 255-284). Montreal: Harmattan.

Bourdieu, P. (2007). O poder simbólico. Rio de Janeiro: Bertrand Brasil.

Brant, L. C., \& Minayo-Gomez, C. (2005). Suffering and its destines in working management. Revista Ciência \& Saúde Coletiva, 10, 939952. http://dx.doi.org/10.1590/S1413-81232005000400017

Brasil (1980). Lei no 6.880, de 9 de dezembro de 1980. Dispõe sobre o Estatuto dos Militares. Rio de Janeiro: Serviço de Documentação da Marinha.

Douglas, M. (1987). Constructive drinking: Perspectives on drink from anthropology. Cambridge: Cambridge University Press.

Fainzang, S. (2007). Curar-se do álcool: Antropologia de uma luta contra o alcoolismo. Rio de Janeiro, Niterói: Intertexto.

Fossey, E., Harvey, C., McDermott, F., \& Davidson, L. (2002). Understanding and evaluating qualitative research. Australian and New Zealand Journal of Psychiatry, 36, 717-732. http://dx.doi.org/10.1046/j.1440-1614.2002.01100.x

Halpern, E. E., \& Leite, L. M. C. (2011a). The construction of the alcoholic habitus and alcohol consumption in the workplace among military patients of Brazilian navy. Cadernos de Saúde Coletiva, 19, 56-365.

Halpern, E. E., \& Leite, L. M. C. (2011b). Deciphering the meanings of navy ethylic behaviors of military patients. Boletim de Psicologia, 61, 177-191.

Halpern, E. E., \& Leite, L. M. C. (2012). The “cooked crab” uniform and the "branquinha": Life narratives of a military alcoholic patient. Cadernos de Psicologia Social do Trabalho, 15, 65-80.

Halpern, E. E., \& Leite, L. M. C. (2013). The connection between sailors' duties and alcoholism. Revista Psicologia: Organizações $e$ Trabalho, 13, 111-126.

Halpern, E. E., Ferreira, S. M. B., \& Silva Filho, J. F. da. (2008). The effects of the labor situations in the construction of the alcoholism of the Brazilian's navy military patients. Cadernos de Psicologia Social do Trabalho, 11, 273-286.

http://dx.doi.org/10.11606/issn.1981-0490.v11i2p273-286

Halpern, E. E., Leite, L. M. C., \& Silva Filho, J. F. da. (2010). Drinking on board: Learned tradition. Antropolítica: Revista Contemporânea de Antropologia e Ciência Política, 28, 151-176.

Malinowsky, B. (1922/1984). Argonauts of the Western Pacific. Illinois: Waveland Press Inc.

Minayo, M. C. S. (2006). O desafio do conhecimento: Pesquisa quailtativa em saúde (9th ed.). São Paulo: Hucitec.

Minayo, M. C. S., Deslandes, S. F., \& Gomes, R. (2007). Pesquisa social: Teoria, método e criatividade (26th ed.). Petrópolis, RJ: Vozes.

Peirce, C. S. (1935). The collected papers of Charles Sanders Peirce, volumes V and VI: Pragmatism and pragmaticism and scientific metaphysics. C. Hartshorne, \& P. Weiss (Eds.), Massachusetts, Cambridge: Harvard University Press.

World Health Organization (1993). Classificação de transtornos mentais e de comportamento da CID-10. Descrições clínicas e diretrizes diagnósticas. Porto Alegre: Artes Médicas Sul.

Yin, R. K. (2005). Case study research: Design and methods. New York: SAGE Publications Inc. 